\section{Phenylketonuria, congenital hypothyroidism and haemoglobinopathies: public health issues for a Brazilian newborn screening program}

\author{
Fenilcetonúria, hipotireoidismo congênito e \\ hemoglobinopatias: questões de saúde pública \\ para um programa de triagem neonatal brasileiro
}

Judy Botler 1

Luiz Antonio Bastos Camacho 1

Marly Marques da Cruz 1
1 Escola Nacional de Saúde Pública Sergio Arouca, Fundação Oswaldo Cruz, Rio de Janeiro, Brasil.

Correspondence J. Botler

Departamento de Epidemiologia e Métodos Quantitativos em Saúde, Escola Nacional de Saúde Pública Sergio Arouca, Fundação Oswaldo Cruz. Rua Leopoldo Bulhões 1480, 8 o andar, Rio de Janeiro, $R J$ 21041-210, Brasil. jbotler@ensp.fiocruz.br

\section{Abstract}

In this study, the frequency of detected congenital hypothyroidism, phenylketonuria and haemoglobinopathies in the State of Rio de Janeiro's (Brazil) Newborn Screening Program (NBSP) was analyzed between the years of 2005 and 2007. There were two Newborn Screening Reference Centers (named NSRC A and B) with programmatic differences. In 2007, overall detection coverage reached $80.7 \%$. The increase in the incidence of congenital hypothyroidism (1:1,030 in 2007) was attributed to the reduction of neonatal TSH value limits over time. The incidence discrepancy of phenylketonuria between NSRC A $(1: 28,427)$ and $B(1: 16,522)$ might be partially explained by the small number of cases. The incidence of sickle cell disease and its traits were uniformly high (1:1,288 and 1:21, respectively). This was coherent with the ethnic composition of the population. The differences in laboratory methods and critical values, in addition to other programmatic issues, may explain the variances in the results and limited analysis of the role of biological and environmental determinants in the occurrence of these diseases.

Neonatal Screening; Phenylketonurias; Congenital Hypothyroidism; Hemoglobinopathies

\section{Introduction}

Newborn screening programs (NBSPs), introduced in the 1970's 1,2 have improved the early diagnosis and treatment of several congenital diseases that are asymptomatic during the neonatal period. Their early detection can improve prognosis and lead to a newborn's full development.

Newborn screening (NBS) tests consist of the analysis of dried blood spots collected on filter paper ${ }^{1}$. The tests have high sensitivity and specificity, but low positive predictive value for infrequently occurring diseases. The NBSP in Brazil includes testing for phenylketonuria (PKU), congenital hypothyroidism $(\mathrm{CH})$ and haemoglobinopathies.

Children with PKU are unable to metabolize Phenylalanine (Phe) which accumulates in the bloodstream causing irreversible damage to the nervous system. Detection from NBS blood spots is based on high levels of plasmatic Phe and treatment consists of dietary protein restrictions ${ }^{3}$. PKU occurrence has varied widely in Europe (between 1:3,042 and 1:35,552 newborns in 2004) 4 and Latin America (between 1:12,473 and $1: 51,989$ in 2005) 5.

$\mathrm{CH}$ is the main endocrine cause of mental retardation in the neonatal period. Early detection and hormone replacement starting no later than two weeks allow normal development 6 . The frequency of occurrences of $\mathrm{CH}$ varies widely in Europe (incidence between 1:1,333 and 1:13,886 
in 2004) 4 but less in Latin America (incidence between 1:1,667 and 1:3,670 in 2005) 5 .

Hereditary haemoglobinopathies affect approximately $7 \%$ of the world population 7 . Deoxygenated haemoglobin makes erythrocytes assume a "sickle-like" shape leading to thromboembolic phenomena and haemolitic anemia ${ }^{8}$. NBS allows the introduction of prophylactic measures that reduce the disease's morbidity and mortality. In 2005, the estimated incidence of the disease in Brazil was 1:2,043 newborns (varying from 1:1,196 to 1:39,107 across studies) 5 .

In Brazil, during the 1980s, various NBSPs were instituted in a disarticulated way until 2001, when the Government created the National NBSP 9 . The program is aimed at providing universal access to the tests and its actions include diagnostic confirmation, treatment and followup for affected individuals free of charge for all citizens.

In each State, Neonatal Screening Reference Centers (NSRC) are responsible for the articulation of the laboratory with the network of collection units and management of all activities related to NBS.

The State Institute of Endocrinology and an independent philanthropic organization have managed the NBSP in the State of Rio de Janeiro since the mid-1980s. From 1994 to 2005, the municipality of Rio de Janeiro ran its own NBSP 10,11,12.

In 2001, the State of Rio de Janeiro was accredited for phase II of the governmental NBSP and has 3 NSRCs. This is a unique situation, considering that the majority of the other Brazilian states have only one NSRC. The 3 NSRCs in the State of Rio de Janeiro were: the State Institute of Endocrinology (Instituto Estadual de Diabetes e Endocrinologia - IEDE), an independent philanthropic organization and a hospital in the Rio de Janeiro municipality 13,14. By 2005, the hospital in Rio de Janeiro city had been deactivated and its test load was transferred to the Institute of Endocrinology. Currently, the Institute of Endocrinology and the independent philanthropic organization share the state of Rio de Janeiro's NBS test demand with independent and distinct workflows. The State Institute of Haematology provides diagnostic and therapeutic support to both for the cases with haemoglobinopathies.

In this study, the frequency of diseases detected in the State of Rio de Janeiro's NBSPs from 2005 to 2007 was analyzed, taking into consideration operational and programmatic aspects of the different NSRCs. Analysis of Rio de Janeiro's NBSP data during these years may be informative as to the strengths and weaknesses of their approaches and is also indicative of the mag- nitude of these target diseases in the State. The analysis of a large-scale government funded NBSP, with intended universal coverage, targeting rare diseases with a short time for effective intervention, raises relevant issues, both from a methodological standpoint and also from a public health perspective, which are the focus of this paper.

\section{Material and methods}

This is a retrospective study based on NBS tests' records collected between 2005 and 2007 by healthcare professionals in 422 collection units distributed throughout 92 municipalities in the State of Rio de Janeiro.

Several differences in the modus operandi across institutions that operated the NSRC were regarded as relevant for the purpose of this research and are described below. In this report, the different procedures were referred to as "NSRC A" (IEDE), "NSRC B" (the independent philanthropic organization), and "NSRC C" (the hospital located in the Rio de Janeiro municipality).

Bloodspots were collected on filter paper (Schleicher \& Schüell 903, Schleicher \& Schüell BioScience Inc., Keene, USA) by heel puncture, preferably between the child's third and seventh day of life 15 . They were submitted to neonatal thyrotropin (TSH) analysis using the immunofluorometric method (AutoDelfia Neonatal hTSH Kit, PerkinElmer Life and Analytical Sciences, Wallac and Oy, Turku, Finland). Laboratory A adopted a cut-off limit of 20.0 $\mu \mathrm{IU} / \mathrm{mL}$ until 2006, when it was reduced to $10.0 \mu \mathrm{IU} / \mathrm{mL}$. Children with levels above these limits were recalled for confirmation with serum TSH and Free- $\mathrm{T}_{4}$ (TSH e FrT4 Automated Chemiluminescence System: 180 - Siemens Medical Solutions Diagnostics, Chicago, USA) (Figure 1).

In NSRC B, the neonatal TSH cut-off limit considered physiological variations with age. For specimens collected between the third and seventh day, with TSH levels above $15.0 \mu \mathrm{IU} / \mathrm{mL}$, a new bloodspot sample was obtained. If the TSH level remained higher than $10.0 \mu \mathrm{IU} / \mathrm{mL}$, the child was submitted to diagnostic confirmation. For NBS samples collected from children over than seven days, the critical level was $10.0 \mu \mathrm{IU} / \mathrm{mL}$. Any level above $25.0 \mu \mathrm{IU} / \mathrm{mL}$ was taken for serum confirmation regardless of the child's age at the time of the blood spot collection. Confirmation was made with serum TSH and Free-T4 using the chemiluminescence method (Symbiosys Diagnostic Ltda., Leme, Brazil). In both NSRCs, confirmed cases were treated with L-thyroxin at a dose of 10 to $15 \mu \mathrm{g} / \mathrm{kg} /$ day 11 . 
1a) NRSC A

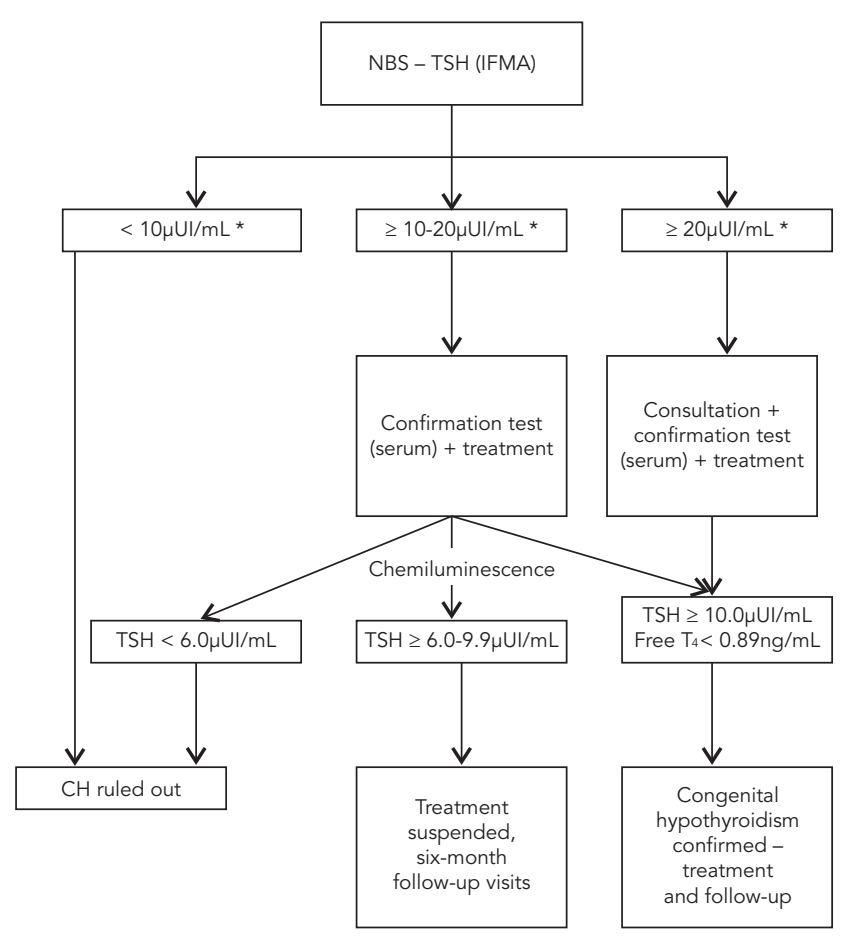

1b) NRSC A

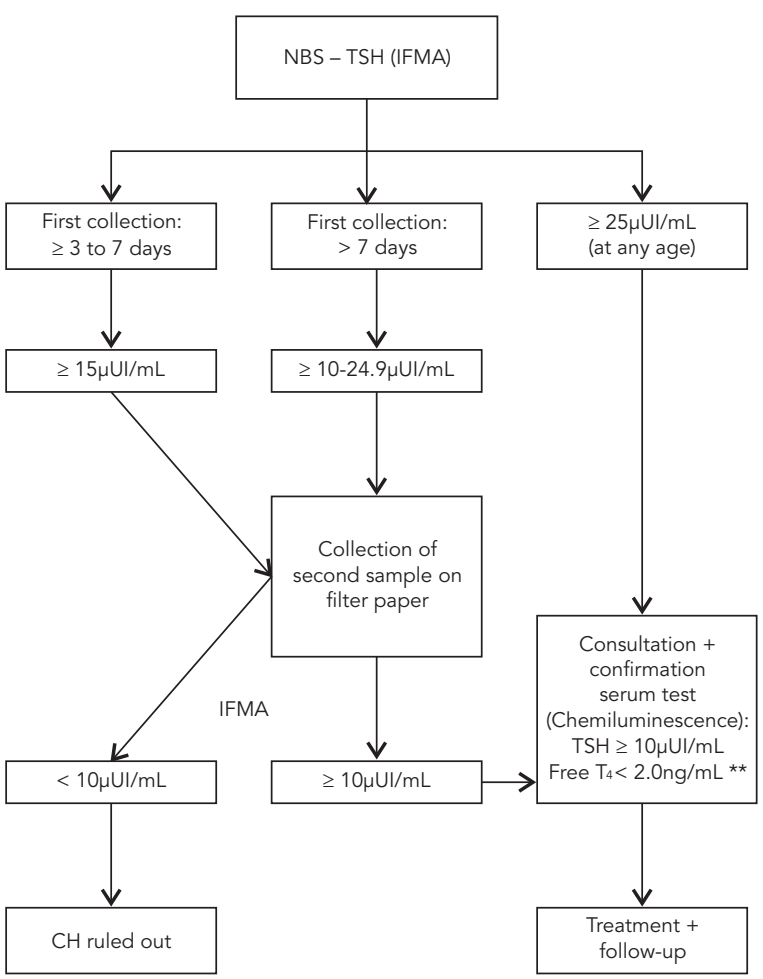

* The neonatal TSH cut-off level used is the same for all samples collected after the first 24 hours of life;

** The free $\mathrm{T}_{4}$ cut-off value (chemiluminescence) for infants between one and four months of life is between 2.0 and $5.0 n g / \mathrm{mL}$.

For Phe assay, laboratory A used the fluorimetric method (Neonatal Phenylalanine Kit, Perkin Elmer Life and Analytical Sciences, Wallac and Oy, Turku, Finland), in which levels higher than $10.0 \mathrm{mg} / \mathrm{dL}$ were subject to a retest with the same method. The persistence of levels higher than $10.0 \mathrm{mg} / \mathrm{dL}$ indicated immediate dietary treatment (Figure 2).

Laboratory B used the colorimetric enzymatic method (NeoLisa PKU Kit; Internacional Científica Ltda., São José dos Campos, Brazil) for Phe determination. In bloodspots collected before the fifth day of life, results between 3.5 and $4.0 \mathrm{mg} /$ $\mathrm{dL}$ were subject to an analysis using another method (thin layer amino acid chromatography) to differentiate from thyrosinemia and full parenteral nutritional treatment. In specimens collected after the fifth day, Phe levels above $5 \mathrm{mg} / \mathrm{dL}$ were subject to a retest on bloodspots. Levels above $10 \mathrm{mg} / \mathrm{dL}$ indicated treatment.
In NSRC A, bloodspots and newborn data were sent to the State Institute of Haematology's lab for $\mathrm{Hb}$ analysis using high performance liquid chromatography (HPLC-Variant - $\beta$-thalassemia Short Program, United States, Bio-Rad Laboratories, Hercules, USA) for detection of S and C hemoglobin. Normal results were returned to the main NBS laboratory and gathered in a single report with other results. Heterozygotes with AS $\mathrm{Hb}$ (sickle cell trait) had a note attached to the report for the family's guidance. Homozygotes with SS Hb (sickle cell disease) were recalled for diagnostic confirmation with the same method, indicating antibiotic treatment and prophylactic management.

In NSRC B, Hb was analyzed in their own laboratory using isoelectric focusing (Resolve Hemoglobin Kit PerkinElmer Life and Analytical Sciences, Wallac and Oy, Turku, Finland) with confirmation by HPLC (Variant - Sickle Short 
2a) NRSC A

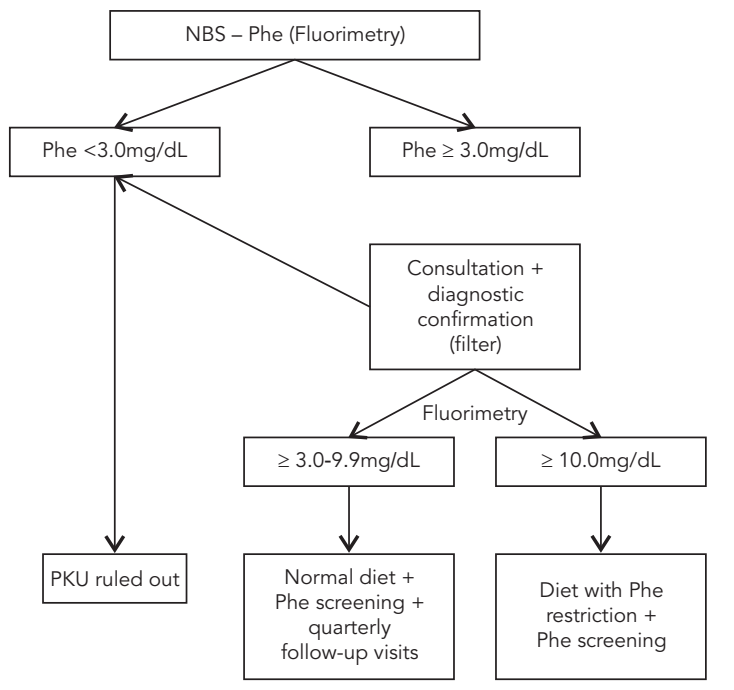

2b) NRSC A B
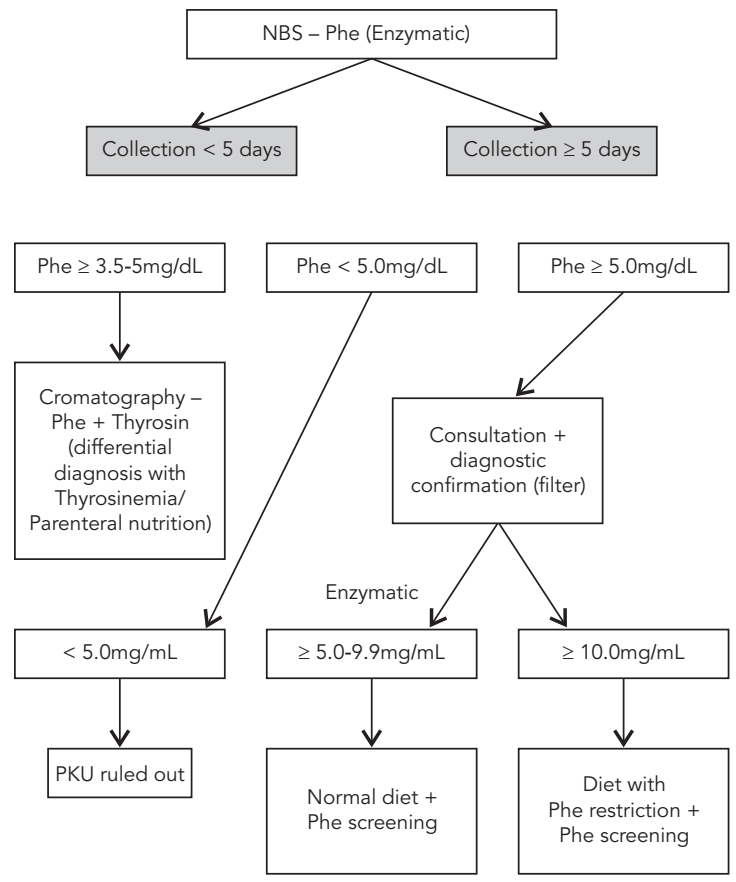

Program, United States Bio-Rad Laboratories, Inc., Hercules, USA) for detection of SS, FC, FSA and FSC Hbs. The procedure for heterozygotes was the same as in NSRC A. Homozygotes for SS $\mathrm{Hb}$ were directly recalled and sent to the State Institute of Haematology outpatient's clinic where the same protocol for detected cases in NSRC A was followed.

In this study, the following indicators were analyzed: coverage, total recalls, recall rate and percentage of confirmed cases in relation to the overall amount of children submitted to testingin accordance with the NRSP approach, during the analyzed period.

Data were obtained by trained healthcare professionals from different sources and refers to the period 2005 to 2007 (except for data used in the calculation of coverage which relates to the period 2002 to 2007). Data were also obtained from the Live Birth Registration System (SINASC; http://www.datasus.gov.br, accessed on 24/Apr/2011), NSRC reports sent to Brazilian Ministry of Health, worksheets and forms, NSRC databases, activity reports, recall documents of second sample collections due to invalid first samples or for diagnostic confirmations, attendance monitoring spread sheets for the recall of second bloodspot collections or diagnostic confirmations. The dominant component of this data was from the public sector. Data from the complementary sector were not available.

Data were entered in MS Excel (Microsoft Corp., USA) spread sheets containing the following variables: child's initials, specimen number, birth date, first collection date, collection unit code, registration date of the first sample, abnormal result, result release date, recall date, arrival date of the second sample/diagnostic confirmation, recall reason in case of invalid sample; reason for no-show and confirmatory results for each analyze (TSH, Free- $\mathrm{T}_{4}$, Phe e $\mathrm{Hb}$ ).

In coverage estimates, the numerator considered the amount of tests carried out in all three NSRCs, and the denominator included the amount of births obtained from SINASC. The frequency calculations for each disease considered all confirmed cases in relation to all the tests carried out, overall and within each NSRC. For 
the incidence calculation, all the children with abnormal results who showed up for diagnostic confirmation were included. The calculation of annual incidence was based on children's birth date. Double entries in the database and cases that had not been submitted to NBS by the laboratory itself were excluded. All data were inserted, checked and analyzed using MS Excel and SPSS 13.0 (SPSS Inc., Chicago, USA).

This research project was approved by the Ethics Research Committee of the Brazilian National School of Public Health, Oswaldo Cruz Foundation (Escola Nacional de Saúde Pública Sergio Arouca, Fundação Oswaldo Cruz - ENSP/ Fiocruz Rulling no. 113/08), by the State Reference Institute in Endocrinology (IEDE Rulling no. 48/08) and by the Board of Management of the independent philanthropic institution by means of their Terms of Agreement. The study was financed by the State of Rio de Janeiro Foundation for Research Support (Fundação de Amparo à Pesquisa do Estado do Rio de Janeiro - FAPERJ Grant no. E-26/111.443/2008) and the National Council for Scientific and Technological Development (Conselho Nacional de Desenvolvimento Científico e Tecnológico - CNPq Grant no. 308651/2006-5).

\section{Results}

Data were collected from October 2008 to May 2009. In NSRC A, data were collected by staff, where as in NSRC B, this work were carried out by the research team. The State Institute of Haematology did not permit access to data regarding haemoglobinopathies and analysis of this disorder was restricted to the National NBSP monitoring reports.

NBSP coverage increased from $71.6 \%$ to $80.4 \%$ during the period under analysis, with an outstanding drop to $65.4 \%$ in 2004 16. Since model C's monitoring reports were not available in 2004 and results were not considered in the calculation, coverage in that year is underestimated. Both the reduction in total births $(7 \%)$ and the increase in the number of tests carried out $(5 \%)$ contributed to the increase in coverage. The transfer of NSRC C's caseload to NSRC A in 2005 increased the latter's participation from $79 \%$ in 2005 , to $81 \%$ of all tests performed in the State in 2007. The remaining caseload was tested by NSRC B. The collection units that comprised NSRC B were smaller and were spread throughout the State in smaller and less populated municipalities.

In 2005, with regard to $\mathrm{CH}$ screenings, the newborn recall rate in NSRC A was twice as high as that in NSRC B, despite the higher TSH cut- off level in NSRC A (Table 1). In 2006, with the reduction in the cut-off level in NSRC A, the recall rate became seven times higher than that in NSRC B. Laboratory methods were different for diagnostic confirmation and the incidence rate in NSRC A increased sharply until 2007, when it was 7.7 times higher than in NSRC B. From 2005 to 2007, the global incidence rate (in both NSRCs) increased by 3.5 times.

With different laboratory methods for PKU screening and confirmation in the two NSRCs, recall rates were lower in NSRC A and detection rates were higher in NSRC B (Table 1).

Despite the different laboratory methods, recall and incidence rates of sickle cell disease and traits were similar in both NSRCs and showed a lower variation with no defined trend during the analyzed period (Table 1).

\section{Discussion}

Estimates in the frequency of the target diseases are essential for adequate planning of specific healthcare programs in addition to providing important information for assessing current early detection programs. Wide geographic and periodic variations of rare diseases such as $\mathrm{CH}$ and PKU may be attributed to genuine variations in diseases frequency or to operational issues such as laboratory methods or program coverage.

The common goal of all NBSPs of $100 \%$ coverage still represents a great challenge even in certain more developed countries. For instance, in 2006, Canada achieved coverage of only $76 \% 17$ and Belgium reported coverage of only $87 \% 4$.

In Brazil, where the goal of the government program is universal access, coverage was $100 \%$ in those states with more advanced program implementation (which includes screening for $\mathrm{CH}$, PKU, haemoglobinopathies and cystic fibrosis). In states in the intermediate stages of implementation (CH, PKU and haemoglobinopathies), coverage ranged from $70 \%$ to $99 \%$, whereas in those in the initial stages (PKU and $\mathrm{CH}$ ) coverage ranged from $3 \%$ to $47 \% 12,18,19,20$.

In 2007, coverage in the state of Rio de Janeiro (81\%) was lower than that of other states in Southeast region, such as São Paulo (88\%) and Espírito Santo (87\%) 12. It was not possible to evaluate from the available data whether the existence of more than one NSRC contributed to test accessibility. NSRC A carried out most of the tests $(81 \%$ in 2007) as it covered a larger number of municipalities with larger populations.

In coverage estimates, the number of live births represents a reasonable approximation to the denominator, since all infants are eligible for NBS. 
Critical values of the different laboratory methods, recall rates and frequency of the diseases detected in the different Newborn Screening Reference Centers (NSRC) of the Neonatal Screening Program in the State of Rio de Janeiro, Brazil between 2005 and 2007.

\begin{tabular}{|c|c|c|c|c|c|c|}
\hline & \multicolumn{2}{|c|}{2005} & \multicolumn{2}{|c|}{2006} & \multicolumn{2}{|c|}{2007} \\
\hline & NSRC A & NSRC B & NSRC A & NSRC B & NSRC A & NSRC B \\
\hline Samples tested & 139,096 & 38,098 & 153,031 & 35,845 & 142,135 & 33,043 \\
\hline \multicolumn{7}{|l|}{ Congenital hypothyroidism } \\
\hline Method (neonatal TSH) & IFMA & IFMA & IFMA & IFMA & IFMA & IFMA \\
\hline Limit value & $\geq 20.0 \mathrm{mUl} / \mathrm{mL}$ & $\geq 15.0 \mathrm{mUl} / \mathrm{mL}$ & $\geq 10.0 \mathrm{mUl} / \mathrm{mL}$ & $\geq 15.0 \mathrm{mUl} / \mathrm{mL}$ & $\geq 10.0 \mathrm{mUl} / \mathrm{mL}$ & $\geq 15.0 \mathrm{mUl} / \mathrm{mL}$ \\
\hline $\mathrm{CH}$ suspects & 116 & 16 & 887 & 27 & 230 & 12 \\
\hline Number of cases & 42 & 7 & 126 & 12 & 165 & 5 \\
\hline Recall (rate per 10,000) & 8.30 & 4.20 & 58.00 & 7.50 & 16.20 & 3.60 \\
\hline Incidence & $1: 3,311$ & $1: 5,442$ & $1: 1,215$ & $1: 2,987$ & $1: 861$ & $1: 6,609$ \\
\hline Overall incidence & \multicolumn{2}{|c|}{$1: 3,616$} & \multicolumn{2}{|c|}{$1: 1,369$} & \multicolumn{2}{|c|}{$1: 1,030$} \\
\hline \multicolumn{7}{|l|}{ Phenylketonuria } \\
\hline Method (phenylalanine) & Fluorimetric & Enzimatic & Fluorimetric & Enzimatic & Fluorimetric & Enzimatic \\
\hline Limit value & $\geq 3.0 \mathrm{mg} / \mathrm{dL}$ & $\geq 5.0 \mathrm{mg} / \mathrm{dL}$ & $\geq 3.0 \mathrm{mg} / \mathrm{dL}$ & $\geq 5.0 \mathrm{mg} / \mathrm{dL}$ & $\geq 3.0 \mathrm{mg} / \mathrm{dL}$ & $\geq 5.0 \mathrm{mg} / \mathrm{dL}$ \\
\hline PKU suspects & 11 & 11 & 11 & 17 & 7 & 7 \\
\hline Number of cases & 5 & 2 & 9 & 3 & 5 & 2 \\
\hline Recall (rate per 10,000) & 0.79 & 2.89 & 0.72 & 4.74 & 0.49 & 2.12 \\
\hline Incidence & $1: 27,819$ & $1: 19,049$ & $1: 17,003$ & $1: 11,948$ & $1: 28,427$ & $1: 16,522$ \\
\hline Overall incidence & \multicolumn{2}{|c|}{$1: 25,313$} & \multicolumn{2}{|c|}{$1: 15,740$} & \multicolumn{2}{|c|}{$1: 25,025$} \\
\hline \multicolumn{7}{|l|}{ Sickle cell disease } \\
\hline Method (hemoglobin) & HPLC & Focusing & HPLC & Focusing & HPLC & Focusing \\
\hline Types of hemoglobin & $\begin{array}{c}\mathrm{Hb} \text { SS, FC, FSA } \\
\text { and FSC }\end{array}$ & $\begin{array}{c}\mathrm{Hb} \text { SS, FC, FSA } \\
\text { and FSC }\end{array}$ & $\begin{array}{c}\mathrm{Hb} \text { SS, FC, FSA } \\
\text { and FSC }\end{array}$ & $\begin{array}{c}\mathrm{Hb} \text { SS, FC, FSA } \\
\text { and FSC }\end{array}$ & $\begin{array}{c}\mathrm{Hb} \text { SS, FC, FSA } \\
\text { and FSC }\end{array}$ & $\begin{array}{c}\mathrm{Hb} \text { SS, FC, FSA } \\
\text { and FSC }\end{array}$ \\
\hline Number of confirmed cases * & 116 & 28 & 104 & 26 & 112 & 24 \\
\hline Incidence & $1: 1,199$ & $1: 1,361$ & $1: 1,471$ & $1: 1,379$ & $1: 1,269$ & $1: 1,377$ \\
\hline Overall incidence & \multicolumn{2}{|c|}{$1: 1,205$} & \multicolumn{2}{|c|}{$1: 1,452$} & \multicolumn{2}{|c|}{$1: 1,288$} \\
\hline \multicolumn{7}{|l|}{ Sickle cell trait } \\
\hline Method (hemoglobin) & HPLC & Focusing & HPLC & Focusing & HPLC & Focusing \\
\hline \multirow[t]{2}{*}{ Types of hemoglobin } & Heterozygote & Heterozygote & Heterozygote & Heterozygote & Heterozygote & Heterozygote \\
\hline & $\mathrm{Hb} \mathrm{S}$ & $\mathrm{Hb} \mathrm{S}$ & $\mathrm{Hb} \mathrm{S}$ & $\mathrm{Hb} \mathrm{S}$ & $\mathrm{Hb} \mathrm{S}$ & $\mathrm{Hb} \mathrm{S}$ \\
\hline Number of confirmed cases * & 5,655 & 1,594 & 7,291 & 1,521 & 6,945 & 1,403 \\
\hline Incidence & $1: 25$ & $1: 24$ & $1: 21$ & $1: 24$ & $1: 20$ & $1: 24$ \\
\hline Overall incidence & \multicolumn{2}{|c|}{$1: 24$} & \multicolumn{2}{|c|}{$1: 21$} & \multicolumn{2}{|c|}{$1: 21$} \\
\hline
\end{tabular}

$\mathrm{CH}$ : congenital hypothyroidism; PKU: phenylketonuria.

* Number of suspected cases not available.

On the other hand, coverage may be inflated since it considers the total amount of bloodspots as opposed to the number of newborns tested. Second samples may have not been distinguished from initial screening tests. Moreover, registers of tests carried out in the private sector, which plays an important role in healthcare system in the State of Rio de Janeiro, were not available and it was not possible to assess to what extent this affected coverage estimates.

The variations found in $\mathrm{CH}$ recall rates and incidences are explained by differences in neonatal
TSH cut-off levels between laboratories and also in the same laboratory over time. The proportion of false positives (non-confirmed suspected cases) was stable in NSRC B and varied strongly in NSRC A, reaching much lower levels than in NSRC B and those reported in literature. There is no way to estimate the proportion of false negatives that are affected by other factors such as age at collection time, conservation, transportation and sample processing.

Large variations in the frequency of $\mathrm{CH}$ were observed in different Brazilian states that used 
the same laboratory method applied in the State of Rio de Janeiro, such as Mato Grosso, with 1:9,448 20, Sergipe, with 1:6,005 19, Bahia, with 1:4,000 21 and Rio Grande do Sul, with 1:2,746 22 . However, the highest incidence was found in Rio de Janeiro (1:1,030 in 2007; Table 2). Even in Ribeirão Preto 18 , where the NBSP uses the same method and cut-off level as NSRC A, incidence was 1:2,595.

Frequency has been increasing over recent years in many countries due to genetic, environmental and socio-cultural factors 4,5,23. Harris \& Pass 23 analyzed $\mathrm{CH}$ epidemiological behavior in the US over a 25-year-period and observed a continuous and pronounced increase in disease incidence that could be attributed to modifications in diagnostic criteria as well as to environmental factors (iodine intake), ethnic composition and reproductive behavior.

Large variations in PKU incidence were also verified in different states. These findings are similar to the cases of Mato Grosso, with 1:33,068 20, Bahia, with 1:22,000 21, Sergipe, with 1:23,036 19, Rio Grande do Sul, with 1:16,229 22, Ribeirão Preto (São Paulo State), with 1:19,409 18 and Rio de Janeiro with 1:25,025 in 2007 (Table 1). Loeber 4 had already demonstrated large variations between different countries in Europe. The order of magnitude of the incidence rates in Rio de Janeiro was similar to those of other Brazilian states. A few cases generated varying but consistently low rates during the period. It is interesting to note that large discrepancies in incidence and recall rates were found in Rio de Janeiro where there were two laboratories using different methodologies. It is possible that one NSRC was overlooking cases while the other, with very high testing sensitivity, was probably recalling a greater proportion of false positives, lowering its efficiency and unnecessarily increasing stress in the newborn family due to mistaken diagnosis.

In Brazil, sickle cell disease has a heterogeneous distribution and frequency is higher in populations with a greater proportion of individuals from African descent (Northeast region and the states of São Paulo, Rio de Janeiro and Minas Gerais). The frequency of haemoglobinopathies in the State of Rio de Janeiro was homogeneous in both NSRCs, and although incidence increased, it was coherent with the ethnicity of the State's population. In 2007, incidence of sickle cell disease in Rio de Janeiro, was 1:1,288 (Table 1), compared to $1: 650$ in the State of Bahia which has the highest incidence rate for this disease in Brazil 21. Although not directly comparable, the data regarding prevalence of sickle cell disease in Rio Grande do Sul (1:39,000) was consistent with the lower proportion of African descendants in that state 24 .

\section{Conclusion}

Screening for rare diseases with pre-clinical phases as short as those of PKU and $\mathrm{CH}$ poses additional challenges to health programs. Considering the territorial extension and demographic heterogeneity of countries like Brazil, and the cost and complexity of health programs such as NBSP, analyses of this type should be regionalized to make the composition of the state disease panels more cost-effective and offer the population maximum benefits. For haemoglobinopathies, despite the less devastating impact on the newborn's development, the benefit of mass screening isa reduction in disease morbidity/mortality with a lower burden on the healthcare system.

The drawbacks of laboratory methods and the cut-off levels used for detecting suspected cases of $\mathrm{CH}$ show a clear need for further discussions regarding this process. In the definition of normality criteria, taking age into account has a biological basis and an empirical demonstration, but its implementation is more difficult from a practical point of view. It is also important to consider environmental, nutritional and reproductive behavior and the diversity of the ethnic composition of the population as determining factors for the variations found in the epidemiological profile as suggested by Harris \& Pass 23 for the case of $\mathrm{CH}$.

Considering that variations in detection frequencies may have resulted from discrepancies in laboratory tests, there is a need for further scrutiny in this process to avoid the implications of false positive and false negative results. 


\section{Resumo}

Neste estudo, foi analisada a frequência de detecção do hipotireoidismo congênito, fenilcetonúria e hemoglobinopatias no Programa de Triagem Neonatal do Estado do Rio de Janeiro, Brasil, entre 2005 e 2007. Havia dois Serviços de Referência em Triagem Neonatal (designados SRTN A e B) com diferenças programáticas. Em 2007, a cobertura alcançou 80,7\%. O aumento na incidência do hipotireoidismo congênito (1:1.030 em 2007) foi atribuído à redução no valor de corte do TSH ao longo do tempo. As incidências discrepantes da fenilcetonúria entre os modelos (SRTN A - 1:28.427; SR$T N B-1: 16.522)$ podem ser parcialmente explicadas pelo pequeno número de casos. A incidência da doença falciforme e do traço falcêmico foi uniformemente elevada (1:1.288 e 1:21, respectivamente), sendo coerente com a composição étnica da população. As diferenças nos métodos laboratoriais e valores críticos, além de outras questões programáticas, podem explicar a variabilidade nos resultados e limitar a análise do papel dos determinantes biológicos e ambientais sobre a ocorrência das doenças.

Triagem Neonatal; Fenilcetonúrias; Hipotireoidismo Congênito; Hemoglobinopatias

\section{Contributors}

J. Botler contributed in all steps of research: project conception, data collection, data analysis, writing and approval of final version. L. A. B. Camacho and M. M. Cruz contributed in the research Project, analysis of results, writing, review and approval of final version.

\section{Acknowledgements}

The study was supported by FAPERJ and CNPq. We are grateful tothe State Health Department of Rio de Janeiro, IEDE and APAE. We are also grateful to Daniel E. T. Duarte for his contribution with data collection and Karla K. F. Costa for her secretarial support activities.

\section{References}

1. Guthrie R, Susi A. A simple phenylalanine method for detecting phenylketonuria in large populations of newborn infants. Pediatrics 1963; 32:338-43.

2. Dussault JH, Coulombe P, Laberge C, Letarte J, Guyda H, Khoury K. Preliminary report on a mass screening program for neonatal hypothyroidism. J Pediatr 1975; 86:670-4

3. Scriver C, Kaufman S, Eisensmith RC, Woo SLC. The hyperphenylalaninemias. In: Scriver C, Beau$\operatorname{det}$ AL, Sly WS, Valle D, editors. The metabolic and molecular basis of inherited disease. New York: McGraw-Hill; 1995. p. 1015-76.
4. Loeber G. Neonatal screening in Europe: the situation in 2004. J Inherit Metab Dis 2007; 30:430-8.

5. Borrajo G. Newborn screening in Latin America at the beginning of the 21st century. J Inherit Metab Dis 2007 ; 30:466-81.

6. American Academy of Pediatrics, Rose SR; Section on Endocrinology and Committee on Genetics, American Thyroid Association, Brown RS; Public Health Committee, Lawson Wilkins Pediatric Endocrine Society, Foley T, et al. Update of newborn screening and therapy for congenital hypothyroidism. Pediatrics 2006; 117:2290-303. 
7. Weatherall DJ, Clegg JB. Inherited haemoglobin disorders: an increasing global health problem. Bull World Health Organ 2001; 79:704-12.

8. Weatherall DJ, Clegg JB, Higgs DR, Wood WG. The hemoglobinopathies. In: Schriver C, Beaudet AR, Sly WS, Valle D, editors. The metabolic and molecular basis of inherited disease. New York: McGrawHill; 1995. p. 3417-84.

9. Ministério da Saúde. Portaria GM/nº 822 - Cria o Programa Nacional de Triagem Neonatal (PNTN). Diário Oficial da União 2001; 7 jun.

10. Botler J. Análise crítica da implantação de um programa de rastreamento para hipotireoidismo congênito no Estado do Rio de Janeiro [Dissertação de Mestrado]. Rio de Janeiro: Pontifícia Universidade Católica do Rio de Janeiro; 1992.

11. Cardoso CBMA. Rastreamento do hipotireoidismo congênito no Rio de Janeiro. In: Medeiros-Neto G, organizador. Hipotireoidismo congênito: como era, como estamos, para onde vamos. São Paulo: Aché; 2004. p. 73-6.

12. Botler J, Camacho LAB, Cruz MM, George PS. Triagem neonatal: o desafio da cobertura universal e efetiva. Ciênc Saúde Coletiva 2010; 15:493-508.

13. Ministério da Saúde. Portaria SAS nº ${ }^{\circ}$ 491. Credencia o IEDE e APAE-RJ como serviços de referência em triagem neonatal. Diário Oficial da União 2001; 23 out.

14. Ministério da Saúde. Portaria SAS no 514. Credencia a Secretaria Municipal de Saúde do Rio de Janeiro como serviço de referência em triagem neonatal. Diário Oficial da União 2001; 5 nov.

15. Secretaria de Atenção à Saúde, Ministério da Saúde. Manual de normas técnicas e rotinas operacionais do Programa Nacional de Triagem Neonatal. Brasília: Ministério da Saúde; 2002.

16. Botler J, Camacho LAB, Cruz MM. Análise do desempenho do Programa de Triagem Neonatal do Estado do Rio de Janeiro, Brasil, de 2005 a 2007. Cad Saúde Pública 2011; 27:2419-28.
17. Therrell BL, Adams J. Newborn screening in North America. J Inherit Metab Dis 2007; 30:447-65.

18. Magalhães PKR, Turcato MF, Angulo IL, Maciel LMZ. Programa de Triagem Neonatal do Hospital de Clínicas da Faculdade de Medicina de Ribeirão Preto, Universidade de São Paulo, Brasil. Cad Saúde Pública 2009; 25:445-54.

19. Ramalho R, Ramalho ARO, Oliveira CRP, AguiarOliveira MH. Evolução do programa de triagem neonatal para o hipotireoidismo congênito e fenilcetonúria no estado de Sergipe de 1995 a 2003. Arq Bras Endocrinol Metab 2004; 48:890-6.

20. Stranieri I. Avaliação do programa de triagem neonatal dos usuários da rede pública - Estado de Mato Grosso 2003-2004 [Dissertação de Mestrado]. Cuiabá: Universidade Federal de Mato Grosso; 2006.

21. Almeida A, Godinho TM, Teles MS, Rehem APP, Jalil HM, Fukuda TG, et al. Avaliação do programa de triagem neonatal na Bahia no ano de 2003. Rev Bras Saúde Matern Infant 2006; 6:85-91.

22. Pinto AB, Wajner M, Goldbeck AS, Vargas PR. Programa de triagem neonatal para fenilcetonúria e hipotireoidismo congênito no Rio Grande do Sul. Rev Méd Minas Gerais 2005; 15(2 Suppl 1):61.

23. Harris KB, Pass KA. Increase in congenital hypothyroidism in New York State and in the United States. Mol Genet Metab 2007; 91:268-77.

24. Sommer C, Goldbeck AS, Wagner SC, Castro SM. Triagem neonatal para hemoglobinopatias: experiência de um ano na rede de saúde pública do Rio Grande do Sul, Brasil. Cad Saúde Pública 2006; 22:1709-14.

Recebido em 26/Dez/2011

Versão final reapresentada em 06/Mai/2012

Aprovado em 25/Jun/2012 